\title{
Hegel on Purpose
}

\section{Arto Laitinen \& Constantine Sandis}

\section{Final Author version of paper forthcoming in Hegel Bulletin}

\begin{abstract}
In this paper we propose a new interpretation of Hegel's views on action and responsibility, defending it against its most plausible exegetical competitors. ${ }^{1}$ Any exposition of Hegel will face both terminological and substantive challenges, and so we place, from the outset, some interpretational constraints.

The paper divides into two parts. In Part I, we point out that Hegel makes a number of distinctions which any sensible account of responsibility should indeed make. Our aim here is to show that Hegel at least has the materials for a sensible and nuanced account, whatever the precise details of how they hang together. Part II then turns to a hard question concerning the relation of two different aspects of our deeds to responsibility. We consider five alternate ways of relieving the tension in Hegel's text, before putting forth our own, preferred, solution.
\end{abstract}

\section{Prologue}

Any interpretation of Hegel's account of responsibility faces the hard problem that he appears to claim two contradictory things, expressed here in the contemporary parlance of foresight:

a) Agents have the right to be held responsible only for those aspects of their deed that were in fact included in their conscious purpose, intention, or foresight (aka their actions).

b) Agents are responsible not only for what was included in their conscious purpose, intention, or foresight (aka their actions), but also for what should have been foreseen in the circumstances (viz. what would have been by a thinking agent). 
Is there a plausible way of understanding these claims so that they both can be upheld, or should one of the claims be dropped?

We discuss a number of possible solutions to this challenge. Each focuses on different key terms in the above pair of conflicting claims. We accordingly discuss six solutions which (1) modify 'responsible', (2) modify 'purpose', (3) extend moral responsibility heroically, (4) modify 'intention', (5) modify 'included', and (6) qualify the 'right' to be held responsible (in one of two ways). Some of these are led to deny that Hegel defends certain distinctions we outline in Part I. By contrast, we hope to show that a solution is available that does not reduce the richness of Hegel's view in this way.

There are two main constraints that should be applied to any proposed solution here. First, a successful solution must remain faithful to the text in preserving those distinctions that he evidently makes. Second, any plausible solution will remain consistent with a broader interpretation of Hegel's overall oeuvre.

In relation to the first constraint, there is, of course, the further question of whether Hegel's own account is sufficiently free from contradiction to adequately deal with all interpretative tensions. One cannot simply assume that if Hegel makes a distinction then it must be a good one, and that if it is a good distinction, then Hegel must have made it. In Part I, we attempt to show that any account of responsibility that makes Hegel's distinctions is indeed a prima facie richer and better equipped than one that does not.

In relation to the second constraint, some further considerations need to be taken into account in the context of our topic:

a) Hegel provides his accounts of action and responsibility mainly in his Philosophy of Right, which presupposes the views defended in his Logic and Phenomenology. Interpretations (such as those of Quante 2004 or Yeomans 2012), which make these links explicit and demonstrate how Hegel's views on action fit in with other aspects of his philosophy are all the more convincing for doing so.

b) Philosophy of Right is divided in three parts. 'Morality', where action and responsibility are discussed, is located between 'Abstract Right' and Sittlichkeit. In 'Morality' some contradictions are developed, but only to be overcome or sublated in the Sittlichkeit section. Such instances are part of Hegel's more general methodology of contradiction; any attempt to relieve tensions in his thought must take this into serious account. 
c) In the 'Morality' section, Hegel discusses three questions (PR: §114): (i) the distinction between external deeds and inner presentations (e.g. conscious purposes) of the deeds; (ii) the nature of the intention or motive or 'interest' or 'subjective value' of the deed for the agent; (iii) the relationship between the value relative to the agent (welfare) and value more objectively (the good). These considerations follow a developmental logic; how Hegel uses some term (e.g. 'purpose') in an early paragraph may differ from how he uses it later on, after further distinctions have been made.

There are further standards which we do not explicitly appeal to here. For example, the contextualist standard of making sense of the relation of any interpretation to the intellectual and historical context in which Hegel wrote. While we hope that we haven't run foul of this (or any other standard), we do not explicitly appeal to it in our arguments. ${ }^{2}$

\section{Distinctions Concerning Responsibility}

We here introduce a number of distinctions that any competent account of responsibility, accountability, chargeability, or imputability should make. Our aim is to show that Hegel has the materials for a sensible and nuanced account (however they ultimately hang together).

\section{Causal and Moral Responsibility}

In Hegel's terminology, causal 'responsibility' should be distinguished from moral 'imputability':

[T]he fact that I am [causally] responsible for something does not mean that the thing can be [morally] imputed to me. (PR: $\S 115 \mathrm{Z})$

Hegel is here effectively distinguishing between what contemporary discussions refer to as causal and moral responsibility. The latter term may be misleading insofar as 'moral' responsibility in its widest sense covers not only moral, but also legal, social, or any other form of normative accountability. Accordingly, we think that what Hegel is really getting at here is a distinction between causal and normative responsibility: between the space of causes and the space of reasons. 
One basic difference, for Hegel, is that 'moral' responsibility only concerns people whereas causal responsibility also covers beings that fall short of his notion of personhood, including new-born babies and non-human animals. Causal responsibility involves bringing something about by playing a role in the causal history of an event. Moral responsibility concerns the appropriateness of praise and blame, evaluations of good or bad intent or motives, and applicability of such notions of wronging and punishment. The volcano Eyjafjallajökull is causally responsible for the delay of certain flights, we do not exercise moral blame, and do not 'impute' the delaying to the volcano or hold it chargeable for it. Hegel uses the term Schuld for causal responsibility (but in ordinary German the term also covers 'guilt', which is a moral notion).

Without taking sides between different translations of Hegel, we use the expressions 'imputing something to me', 'holding me accountable' and 'holding me chargeable' to mean 'holding me morally responsible'. This should be distinguished from holding someone causally responsible. We reserve the plain term 'responsible' for cases that are unclear, ambiguous, vague, or unspecified with regard to causal and/or moral aspects

\section{Deeds and Other Alterations}

Hegel distinguishes between 'deeds' brought about by the agent and other alterations in the external circumstances. What he calls 'a deed' is also an alteration in the external circumstances:

[T] he action of the will presupposes an external object [Gegenstand] with various attendant circumstances. The deed posits an alteration to this given existence [Daseyn], and the will is entirely responsible for it in so far as the abstract predicate 'mine' attaches to the existence so altered. (PR: $§ 115)$

Hegel further connects responsibility to accountability:

I can be made accountable for a deed only if my will was responsible for it. (PR: $§ 117)$

A deed is a very broad category, including things done accidentally, such as dropping a vase when trying to open a window. In a 'deed', there are two elements present, the 'outer' element of the alteration and the 'agential' or 'inner' element - the agent's will is in some direct or indirect way causally connected to the alteration. ${ }^{3}$ The crucial point for causal responsibility, 
which is also relevant for moral responsibility, is the causal connection between these two elements. ${ }^{4}$ We may loosely refer to the 'inner' element corresponding to the entirety of the deed (but not other alterations) as 'the will as a causal factor', or perhaps 'the will as a responsible factor'; Hegel will reserve 'purpose', 'intention' and 'aim/end' for more specific aspects of the deed.

In a prediction such as 'we bet the volcano will erupt again this Saturday making it impossible for us to fly back on Monday' we have an inner pre-conception, and an external event, but no causal connection, so despite our prediction we have no causal (or thereby, moral) responsibility for the eruption of the volcano. This remains true even if we had an evaluative attitude, for example fear or wish or desire that the volcano would erupt. The eruption is not an alteration in the external circumstances to which our will is responsible. A wish or a fear may come true and yet causal responsibility need not be at stake. On the other hand, dropping a vase can be one's deed even if one did not will or want the vase to drop-it is sufficient that one willed something (else) and because of that acted in such a way that the vase was dropped.

Hegel's moral theory in Philosophy of Right rejects the Kantian notion that a morality whose standpoint is the will should restrict itself to 'inner' motives. ${ }^{5}$ It does this by externalising the agent's purpose and intention: purpose and intention are indeed something 'inner' as well, but they are introduced in relation to the agent's deed, understood as behaviour and its consequences. As we will see, actions are externalizations of such purpose. ${ }^{6}$ While a welcome change of perspective, it is notable that this choice of a starting point is not innocent. Indeed, we shall see how Hegel's definition of deed as 'alteration' can lead to difficulties when discussing responsibility for omissions, failures to act, or especially actions which successfully prevent alterations in the circumstances (e.g. keeping the door closed so that the wind doesn't open it). Whatever the truth concerning responsibility for non-deeds, we can agree that causal responsibility is necessary for moral responsibility (chargeability) for deeds, since deeds imply causal responsibility by definition.

\section{Aspects of the Deed Not Included in One's Purpose}

Causal responsibility may be necessary, but is not sufficient for moral chargeability concerning deeds. It does not follow that everything I am causally responsible for may be imputed to me (see $P R: \S 115 Z$ ):

It is, however, the right of the will to recognize as its action, and to accept responsibility for, only those aspects of its deed which it knew to be presupposed 
within its end, and which were present in its purpose. - I can be made accountable for a deed only if my will was responsible for it. (PR: §117)

Hegel holds that agents are accountable (morally responsible, chargeable) only for what is included in the purpose ('Vorsatz') of their deeds. While this leads to a puzzle (discussed in Part II), he at least raises the question (as any sensible account of responsibility must) of whether or not we are chargeable for absolutely everything (viz. every aspect of) in our deeds. Hegel illustrates this with a comparison to Oedipus's responsibility for parricide. Oedipus was causally responsible for the death of his father, but did not know that it was his father that he killed. He may of course be morally responsible for an intentional killing (or at the very least striking), but less obvious whether (and, if so, in what sense) it is appropriate to hold him morally responsible for an act of 'killing one's father':

My will is responsible for a deed only insofar as I have knowledge of it [...] Oedipus, who unwittingly killed his father, cannot be accused of parricide. $(P R: \S 117 \mathrm{Z})^{8}$

For Hegel, inner 'purpose' serves to distinguish those aspects of the 'deed' that count as one's 'action' from those that don't (e.g. the unforeseeable contingent consequences). Whether or not we think (or think that Hegel thinks) that some actions are not deeds, it can be agreed that being part of one's purpose - or being presupposed, predicted, or proposed by it - is what distinguishes actions from other aspects of deeds. ${ }^{9}$ Hegel claims that it is indeterminate which consequences are 'accidental', and external to the nature of action, and which are 'necessary' results, belonging to its nature as consisting of intertwined 'units' $(P R: \S 118 \mathrm{R})$. In so doing, he anticipates Bernard Williams' claim that 'one's life cannot be partitioned into some things that one does intentionally and other things that merely happen to one' (Williams 1993: 69-70). Indeed, Hegel predates Bowra (1944: 168ff.), Dodds (1951: 30ff.), Williams (1976), and Nagel (1976), in considering the relation of moral luck to responsibility. While pretty much everything about moral luck is contestable, including Hegel's take on it, it is a virtue of his account that it leaves space for both raising and answering questions about moral luck (see Sandis 2010, 47$8)$.

Action ('Handlung') is the purpose of the moral/subjective will in the sense that it is its externalisation $(P R: \S 114) .{ }^{10}$ Hegel characterizes action as the 'translation' of the conscious purpose into the external reality; if one's purpose is to build a house, and a house comes into existence through one's interventions, that state of affairs 'contains' or embodies the same content as the original, merely mental purpose. The right of the moral will includes, first of all: 
The abstract or formal right of action, according to which the content of my action, as accomplished in immediate existence [Daseyn], is entirely mine, so that the action is the purpose of the subjective will. (PR: §114)

It is the right of the will to recognize as its action, and to accept responsibility for, only those aspects of its deed which it knew to be presupposed within its end, and which were present in its purpose. The 'right of knowledge' states that one can be made morally accountable, chargeable, for a deed only if one's will was responsible for it (PR: §117). Consequences of deeds may be (i) intended, (ii) foreseen, or (iii) unforeseen: Purpose encompasses the first of these, but not the third:

The will thus has the right to accept [moral] responsibility ${ }^{11}$ only for the first set of consequences, since they alone were part of its purpose. (PR: §118)

In Part II we compare extensive readings of 'purpose' as including (mere) foresight to narrower ones in which it is excluded.

\section{Ownership and Omission}

Hegel sensibly holds that one may be chargeable for something that one did not bring about oneself. That is to say, there is no requirement of causal responsibility for everything that one is morally chargeable or accountable for:

It is admittedly not of my doing if damage is caused to others by things of which $I$ am the owner and which, as external objects, exist and function within a varied context (as may even be the case with myself as a mechanical body or living entity). But the damage is more or less my fault, because the things which caused it are after all mine, although they are in turn only more or less subject to my control, supervision, etc., according to their own distinct nature. (PR: §116)

If our dog bites someone, we may be responsible for something that $i t$ did. In general, if we are the owners of some physical thing, which is causally responsible for some harm (e.g. a wall from which a brick falls onto someone's head) then we are (to a greater or lesser degree) chargeable for it. Perhaps this is so only in cases where the owner does not take appropriate 
measures to prevent such harms, and there was thus some fault in his or her behaviour (failing to take due care). But there are possibly also cases of 'strict liability' where the owner is liable even though he or she did take due care: a sausage factory owner may be liable for sausages containing salmonella even though it was not the factory owner's fault. ${ }^{12}$

Such ownership cases differ from those of natural events (as in the volcano case above) to which we have neither a causal nor a moral relationship in the straightforward way that we do for what we own. Recalling that Hegel has this wider notion of chargeability leaves room for the argument that it may not ultimately matter that his definition of deeds leaves out omissions or active preventions of alterations. One could hold that one is responsible for them, just as one is responsible for things one owns, and that Hegel has the resources to make the required distinctions here. But such a defence would not remove the following sense of unease: opening the door and keeping the door closed should arguably be treated on a par by any sensible account of responsibility. Accordingly, it seems prima facie plausible for the relevant factor to be the active causal control, not the presence of alteration in the circumstances. By contrast, it is reasonable to debate whether acts and omissions should always (or even ever) have the same status. $^{13}$

Intention, Aims, Means, \& Foreseen Consequences

While Hegel thinks that we may be chargeable for the entirety of an action (without being chargeable for the other aspects of the deed), he makes a number of further distinctions that affect more detailed assessments of the agent and action, such as that of the action's 'meaning' (cf. Scanlon 2009). We are thus told that the content of intention ('Absicht') is the aspect of a person's action that constitutes her aim or end ('Zweck'), in so far as she is aware of it ( $P R$ : $\S 114)$. The intention cannot be entirely separated from the action (as a distinct cause), and seems to include awareness of the universal quality of it (cf. PR: $\S 120$ and $\S 118 \mathrm{Z}$ ); the direct character of the action in its further content is a means to this end (PR: $§ 122)$ :

\footnotetext{
The particular aspect of the action is its inner content, [...] i.e. the manner in which its universal character is determined for me - this constitutes the value of the action and the reason why I consider it valid, i.e. its intention. (PR: $§ 114)$
}

Other aspects may be merely foreseen, or taken as a means to an (intended) end. So, how are purpose (Vorsatz) and intention (Absicht) related? ${ }^{14}$ Hegel writes: 
The purpose, as emanating from a thinking agent, contains not just the individual unit, but essentially that universal aspect already referred to — the intention. (PR: §119)

Purpose contains intention as its (universal) aspect. It is tempting to here think of the universal aspect in terms of the type of action (with desirable characteristics) to be performed. On such a picture, various so-called tokens, which differ from one another in irrelevant details, could have done equally well; what they must all have in common may be viewed as the 'universal' aspect. ${ }^{15}$ Given that intention is just an aspect of the purpose, the purpose contains features other than the intention, which has been abstracted from them:

[The word for] intention contains in its etymology [the idea of] abstraction, either as the form of universality or as the selection of a particular aspect of the concrete thing [Sache]. To attempt to justify something in terms of its intention is to isolate an individual aspect completely and to maintain that it is the subjective essence of the action. (PR: $§ 119 \mathrm{R})$

Hegel seems to share the Socratic notion that we always aim at or desire what we think is good. ${ }^{16}$ Intention might thus be said to be the action's desirability characterisation (cf. Anscombe 1957, Wood 2010) or the description under which it is good or desirable in the eyes of the agent. Allen Wood illustrates the distinction between intention and purpose with the example of a bomber pilot. The pilot is out to destroy a military target, but is aware that bombing the military target has the foreseen side-effect of killing innocent children. While the purpose of the action is said to include the deaths of the children (after all, the pilot is morally responsible for their deaths, and if one is morally responsible only for what is included in one's purpose, then one's purpose can be argued to cover such foreseen consequences), the bomber's intention does not include it. His intention is to (help) win the war, and the means to fulfilling it is to bomb the military target.

In debates concerning the Doctrine of Double Effect such cases are often contrasted with the morally worse cases of 'terror bombing', in which innocent civilians are being bombed in order to shake the morale of the enemy combatants. The intention is to end the war, and the innocent civilians are bombed as a means to this. 'Purpose' thus covers the end, means, and foreseen side-effects of action, whereas 'intention' only covers its end.

\section{What One Should Have Foreseen}


Hegel holds further that agents are chargeable not only for what they did in fact foresee, but also for what they should have foreseen, but negligently failed to. What he calls the Right of Objectivity is the right (of the action for the agent) to be held accountable in relation to those unforeseen consequences that one could have foreseen which belong to the subset of consequences that one would have foreseen upon rational reflection (and therefore should have been foreseen):

\footnotetext{
The right of intention is that the universal quality of the action shall have being not only in itself; but shall be known by the agent and thus have been present all along in his subjective will; and conversely, what we may call the right of the objectivity of the action is the right of the action to assert itself as known and willed by the subject as a thinking agent. (PR: §120)
}

In contemporary literature, there is a substantive debate on whether we are or are not responsible for something we should have known but didn't. ${ }^{17}$ Hegel's position on this is clear: an agent can indeed be responsible for such things and to treat someone otherwise is to treat them, in Hegel's own words, like a 'child', 'imbecile', or 'lunatic' whose responsibility is either totally absent or diminished $(P R: \S 120 \mathrm{R}) .{ }^{18}$

\section{The Hard Problem and Six Solutions}

With the help of the distinctions outlined in $\S \mathrm{I}$, we can now formulate the desideratum that a satisfactory account of responsibility would take a stand on the agent's responsibility for:

i) the intention, aim or end in the narrow sense

ii) the foreseen aspects

iii) what should have been foreseen (and would have been by a rational agent, with a bit of reflection)

iv) the means taken (as opposed to merely $\mathrm{i}$ or ii)

v) the moral luck factor of known unknowns

and also

vi) some 'non-deeds' such as (a) bricks falling from a building we own or our unleashed dog biting someone and (b) possibly, by extension, omissions and active preventions of alterations; 
but not hold the agent responsible for

vii) absolutely everything in the deed.

We have tried to show that Hegel makes the distinctions required by this multi-pronged desideratum, with the exception of (vi-b). Since Hegel has (vi-a), he can at least allow that we are responsible for omissions and preventions, despite the fact that they are not officially 'deeds'. 19

A much more serious problem is that (i-iii) collectively create the substantive difficulty of how to square Hegel's claims that:

a) Agents have the right to be held responsible only for those aspects of their deed that were in fact included in their conscious purpose or intention or foresight, viz. their actions.

b) Agents are also responsible for what was not included in their conscious purpose or intention or foresight (viz. their actions) but should have been foreseen in the circumstances (because this would have been by a thinking agent).

Thesis (a) seems to imply that we are not accountable for what we did not foresee. By contrast, thesis (b) explicitly asserts that we are accountable for such things, as long as they were foreseeable, and should have been foreseen.

We now turn to discuss six possible solutions to this hard problem. These, in turn, (1) modify 'responsible', (2) modify 'purpose', (3) extend moral responsibility heroically or (4) modify 'intention', (5) modify 'included' or (6) qualify the 'right' to be held responsible. We shall give preference to those solutions which preserve the rich view of responsibility outlined in Part I.

\section{(1) Modifying 'Responsible'}

The first solution is to distinguish between two senses of 'responsibility', namely (i) full moral chargeability and (ii) mere causal responsibility. This allows for the view that theses (a) concerns morally chargeability, while thesis (b) is only concerned with causal responsibility. If so, then Hegel can consistently maintain that (a) we are only chargeable for consequences that 
are part of our intention, ${ }^{20}$ yet (b) remain causally responsible for any foreseen or unforeseen consequences that result from the will's purpose.

In itself, the distinction appealed to is good, as far as it goes. We have also seen (in Part I) that Hegel himself does indeed draw it. Nonetheless, we believe that solution (1) applies the distinction in the wrong place. In particular, it fails to do justice to Hegel's own illustration: an agent is chargeable if it is the case that she would have known upon reflection that putting fire into one stick of the wooden building would burn the whole thing down (cf. $P R$ : $§ 119$ ): chargeability thus goes beyond our intention. Further, as we have already seen, Hegel holds that chargeability can extend over things we are not causally responsible for, but which we nonetheless own (as in the case of strict liability). Consequently, appealing to the difference between moral and causal responsibility in this way solves the problem at too great a cost, leading to an impoverished view of moral responsibility. Solution (1) must therefore be rejected.

\section{(2) Modifying 'Purpose'}

The second suggested solution goes as follows: agents are chargeable with foreseen and foreseeable consequences, because these are part of their purpose even if they do not seem to be part of their intention. ${ }^{21}$ So conceived, the notion of 'purpose' becomes a highly technical one for Hegel: one does not merely will the means to one's ends or aims, one also wills the foreseen and (certain) unforeseen effects of them. 'Purpose' would thus include: (a) what is intended; (b) what is (merely) foreseen; (c) what the agent would have foreseen upon reflection (and therefore should have foreseen).

This proposal contains a rich view on chargeability, one that does not impoverish Hegel's distinctions. But the term 'purpose' is here used very idiosyncratically. How can something that was not even foreseen be part of one's purpose? More importantly, such a modified use does not seem to fit the way in which Hegel himself distinguishes the action's inner purpose from its external alterations. We should only accept such a problematic solution if no better one can be proposed.

\section{(3) Extending Chargeability (Heroically)}

A third potential solution is that of extending chargeability to include strict liability (viz. everything in our deeds), without renouncing our subjective freedom. This goes back to the idea 
that Oedipus is chargeable with patricide. ${ }^{22}$ The suggestion is heroic in its revisionism. After all, Hegel goes out of his way to say that the Greeks were tragically mistaken to extend chargeability in this way:

The heroic self-consciousness (as in ancient tragedies like that of Oedipus) has not yet progressed from its unalloyed simplicity to reflect on the distinction between deed and action ... but accepts responsibility for the deed in its entirety. $(P R: \S 118 \mathrm{R})^{23}$

Mark Alznauer writes:

Hegel wants to establish a fully modern and self-conscious form of ancient heroism, a way to accept [chargeability] for the entirety of what we have done without renouncing our subjective freedom. (Alznauer 2008: 384)

Hegel thinks we must accept both that someone can only be held [chargeable] for what they intended, and that agents are fully [chargeable] for everything in their deeds. Establishing whether Hegel can coherently assert both of these theses, or whether that amounts to an attempt to eat his cake and have it too, is one of the central burdens facing any full interpretation of Hegel's theory of action. (ibid.)

It can perhaps be granted that Hegel wants to have his cake and have it too. But the 'cake' is not that agents are chargeable for everything in their deeds. Rather, it would seem that agents are chargeable for everything in the universal content or nature of their actions, which does not include all that is included in the deed. There are aspects of deeds that agents are not to chargeable for. Alznauer appears to suggest that a strict liability for everything in the deed exists, regardless of whether or not it was foreseen, foreseeable, and so on. He here draws heavily on Hegel's endorsement of the dictum 'a flung stone is the devil's'. But his way of doing so threatens to empty the very point of the distinction between deed and action. Hegel (§118) thinks it is indeterminate which ('necessary') consequences are to be imputed to the agent, as belonging to the nature of the action, and which ('contingent') ones are not, being external to the nature of the action. But does not follow that the distinction is not (or even that Hegel thinks it is not) a valid one. There are clear cases of consequences that are to be imputed to the agent, and clear cases of consequences that are not to be so imputed.

(4) Modifying 'Intention' 
The fourth proposed solution is closely related to the second. The only difference is that it focuses on 'intention' instead of 'purpose'. ${ }^{24}$ The proposal is thus to modify 'intention' so that what counts as intentional includes anything which would credibly fall under a description of the action which we could give upon rational reflection. Thus, for example, if an action is intentional under the description 'water drinking' then the agent also intended to drink a liquid. By contrast, Oedipus' action of killing the old man is not intentional under the description 'killing one's father' because mere rational reflection would not have revealed the relevant fact to him (cf. Davidson 1967: 147-8). According to the proposed modification, what counts as intentional would further imply that things that are external consequences under one such description are part of the action under another description. Consequences are here swallowed up by through re-description e.g. if we kill you by intentionally shooting you in the heart, then we might follow Donald Davidson (1969) in re-describing our shooting you as our killing you. If so then your death would not be a consequence of the immediate act but its resulting part, and thereby arguably part of its nature as intended. ${ }^{25}$

To illustrate with a further example: suppose there is a delay in a flight because someone tried to bring in some liquid, and may thus be responsible for delaying the flight. Now suppose the person only intended to bring in a very runny cheese, and did not realize this would violate the prohibition in question, and did not intend to delay the flight (or even rationally foresee that it would). She knows that trying to bring in liquid might delay the flight, and upon rational reflection she would have known that runny cheese may be treated as a liquid. This solution states that nonetheless, it was part of the 'intention', because trying to bring in the cheese is trying to bring in a liquid which, in turn, is risking that the flight will be delayed.

The same objection as to suggestion 2 can be made here: how can something that was unforeseen be part of one's intention? We should not even grant that foreseen consequences are part of one's intention. We can grant that the act of bringing about foreseen consequences is intentional, without those consequences being part of one's intention. H. L. A. Hart ${ }^{26} \operatorname{discusses}$ Glanville Williams' case of a mad brain scientist who wants to conduct a successful brain surgery (swapping the brains of two people), reaping the rewards that a successful operation would bring with it. He has failed in all previous 47 cases and chances are that he will fail again. The scientist does not intend to kill the patients, for he is doing his utter best to make the surgery successful. Nonetheless he foresees that in all likelihood the patients will die. Hart points out that scientist can be charged with killing them intentionally, while not having intended to kill them: one cannot move from 'intentionally did' to 'intended to do $\mathrm{x}$ '. ${ }^{27}$ Yet the suggested 
solution is committed to just this, with the additional difficulty of having to explain how unforeseen aspects are to be included in one's intention. ${ }^{28}$

\section{(5) Modifying 'Includes'}

A fifth attempted solution re-interprets the term 'includes' in thesis (a). Although unforeseen aspects are not included in the purpose or intention in the same way that the conscious ends or foreseen side-effects are, they may perhaps still be included in the extended sense that one may be implicitly committed to what one is not explicitly aware of. The agent's 'purpose' may not have the normative element (what one should have foreseen) as its proper part, but it is its normative consequence or implication.

This view preserves the richness of Hegel's distinctions concerning responsibility. In principle, it also fits well with the Hegelian idea that the 'truth' of any immediate aspect may turn out to be something mediated and complex. Nevertheless, in the case at hand, tinkering with the concept of 'include' is not very persuasive, either textually or conceptually. In addition, once we broaden 'including', Oedipus's action (as opposed to his deed) would appear to include killing his father, a view which we have already seen Hegel rejects explicitly.

\section{(6) The 'Right' Solution}

The sixth - and our preferred-solution rejects the strict view that agents are to be held chargeable only for what was in their purpose, while holding on to the view that agents nonetheless have a right of some kind, to be held chargeable for what was in their purpose (and nothing more). 'Purpose' includes only what the agent consciously intended and foresaw, and not what she should have. Our solution endorses (b) that chargeability covers what should have been foreseen, rejecting the strict view that agents are to be held chargeable only for what was in their purpose. But it also endorses (a) that agents have a right of some kind, to be held chargeable for what was in their purpose only. The right in question (the agents' right to knowledge; right of intention), however, is not an absolute one; it is opposed, for example, by the right of objectivity.

Our solution comes in two forms: the 'spheres of culpability' version and the 'change of the subject' version. The first of these distinguishes spheres of chargeability: murder, manslaughter, heat of passion, etc. These are different combinations of the following principles: 
a) The right of intention is the right to only be charged (viz. accept moral responsibility) for intentionally bringing about those effects that one intended (and to repudiate the imputation of any other consequences).

b) The right of knowledge/will is the right to only be charged for knowingly bringing about effects that one foresaw, regardless of whether or not they also intended them (and to repudiate the imputation of any other consequences).

c) The right of objectivity is the right (of the action for the agent) to be held accountable in relation to those unforeseen consequences that one could have foreseen which belong to the subset of consequences that one would have foreseen upon rational reflection, and therefore should have foreseen.

The above 'spheres of culpability' allow that we may be causally responsible for 'owned' sideeffects that fall beyond the scope of the above rights, but that we cannot be charged (viz. accept moral responsibility), in any of the above senses, for bringing them about. On this reading, the various aspects of right are the conceptual apparatus through which Hegel is able to make finegrained moral judgements. The accountability of one who is guilty for failing to foresee certain consequences may be mitigated by their right of knowledge, and that of one who foresees (but does not intend) certain unfortunate consequences, by their right of intention. Rights are real, but not absolute - their interplay with other rights determines the full picture.

How does the 'change the subject' version differ from this? Whereas the previous version held that the right of objectivity is (paradoxically) a subjective right, this version changes the subject of the right of objectivity: The agent, viz. the subjective will, has the right to accept moral responsibility only for the intended and foreseen aspects of the deed. These rights are opposed by the right of objectivity, where the bearer of the right is not the agent as an individual, but rather 'universal will' or 'objective will', which can take the shape of other people or institutions criticizing the person for not foreseeing what they should have, could have, or would have done had they deliberated well.

Put another way, the objective right of the world against the individual is mirrored by a subjective right to be treated as a sane, adult, agent with dignity, that can take responsibility for the claims made against it (hence Hegel's talk of a 'right to punishment'). ${ }^{29}$ But the two rights can clash, and while the subject has the 'right' to be held responsible only for what was included in her purpose, the right of objectivity entails that the subjective right can be overridden. This version of the solution is 'conflictual' insofar as it allows that that these aspects of 'right' can indeed conflict, and that such conflict is predictable given the restrictions of Moralität. Only 
when Sittlichkeit is taken into account more fully, can such conflicts be overcome. The most central conflict, in this respect, is that between conscience and evil. But that, as they say, is a topic for another paper.

\section{Epilogue}

Hegel's insight is that questions of the form 'was A responsible for $\mathrm{X}$ if she did not intend it?' are hopelessly. For it may be that $\mathrm{A}$ is responsible qua knowledge but not qua intention, or responsible qua objectivity but not qua knowledge. As with causal responsibility, there is no such thing as being morally responsible tout court. One can of course be charged for doing something both knowingly and intentionally, but this would involve dropping the exclusivity qualifier 'only'.

Both versions of the 'right' solution remove the contradiction of the hard problem by combining the existence of a subjective right with the belief that certain Hegelian rights can be overridden by other one's rights. They also preserve the tensions in the Morality-section of Philosophy of Right, which remain to be overcome in the following Ethical Life-section.

Finally, our solution also serves as a response to a worry that can be raised against any solution that attempts to erase a contradiction in Hegel (this includes the other five that we discuss). The worry is that Hegel's system actually requires contradictory concepts to give expression to the progress of thought about these issues. ${ }^{30}$ If his dialectic simply is one of contradiction, is there really a need for a solution at all? The answer is 'yes', because a position vis a vis responsibility that includes all tensions yet sublates the contradictory views is - by Hegel's own lights - preferable to one that remains contradictory. ${ }^{31}$ On this ground too, then, the 'right' solution is the right solution. ${ }^{32}$

\section{References}

Alznauer, M. (2008), 'Hegel on Legal and Moral Responsibility', Inquiry: An Interdisciplinary Journal of Philosophy, 51 (4), 365-89.

Alznauer, M. (2015), Hegel's Theory of Responsibility. Cambridge: Cambridge University Press.

Anscombe, G. E. M. (2000 [1957]), Intention. Cambridge MA: Harvard University Press. 
Bowra, M. (1944), Sophoclean Tragedy. Oxford: Clarendon Press.

Dodds, E. R. (1951), The Greeks and the Irrational. Berkeley CA: University of California Press.

Cargnello, D. P. (2014), 'Beyond Morality: Intentional Action in Hegel's Philosophy of Mind', Mind 123 (491), 671-706.

Davidson, D. (1963), 'Action, Reasons and Causes'; as reprinted in Davidson 2001, 3-19.

Davidson, D. (1967), 'The Logical Form of Action Sentences'; as reprinted (with 'Criticism, Comment, and Defence'), in Davidson 2001, 105-48.

Davidson, D. (1969), 'The Individuation of Events'; as reprinted in Davidson 2001, 163-80.

Davidson, D. (2001), Essays on Actions and Events, $2^{\text {nd }}$ revised edition. Oxford: Clarendon Press.

Denham, A. (2014), 'Tragedy Without the Gods: Autonomy, Necessity and the Real Self', British Journal of Aesthetics, 54 (2), 141-59.

Falkenstern, R. (2018), 'Hegel on Sophocles' Oedipus the King and the Moral Accountability of Ancient Tragic Heroes', Hegel Bulletin, 1-18, doi:10.1017/hgl.2018.1.

Hart, H. L. A. (1968), Punishment and Responsibility: Essays in the Philosophy of Law. Oxford: Oxford University Press.

Hegel, G. W. F. (1991 [1821]), Elements of the Philosophy of Right [PR], ed. A.W. Wood, trans. H. B. Nisbet. Cambridge: Cambridge University Press.

Kenny, A.J.P. (2005), 'The Philosopher's History and the History of Philosophy', in Sorell \& Rogers 2005, 13-24.

Knobe, J. (2003), 'Intentional Action and Side Effects in Ordinary Language', Analysis, 63, 190-93.

Knowles, D. (2010), 'Hegel on Actions, Reasons, and Causes', in Laitinen \& Sandis 2010, 42 58.

Knox, T. M. (1942), 'Translator's Notes', in his translation of Hegel's Philosophy of Right (Oxford: Oxford University Press), 298-376.

Knox, T. M. (1968), Action. London: George Allen and Unwin.

Laitinen, A. (forthcoming), 'Hegel and the Guise of the Good', Philosophical Explorations.

Laitinen, A. \& Sandis, C. (eds.) (2010), Hegel on Action. Basingstoke: Palgrave Macmillan.

Laitinen, A., Mayr, E. \& Sandis, C. (2018), 'Kant and Hegel on Action in Ethics', Philosophical Explorations, Vol. 21 (1), 90-107; reprinted in C. Sandis (ed.), Philosophy of Action from Suarez to Anscombe (London: Routledge), to which any page numbers refer. 
Nagel, T. (1976), 'Moral Luck', Proceedings of the Aristotelian Society, Supplementary Volume 50, 137-51.

Pippin, R. B. (2010), 'Hegel's Social Theory of Agency. The 'Inner-Outer' Problem' in Laitinen \& Sandis 2010, 59-78.

Quante, M. (2004 [1993]), Hegel's Concept of Action, trans. D. Moyar. Cambridge: Cambridge University.

Sandis, C. (2009), 'Contextualist vs. Analytic History of Philosophy: A Study in Socrates', Think, 8 (22), 101-105.

Sandis, C. (2010), 'The Man Who Mistook his Handlung for a Tat: Hegel on Oedipus and Other Tragic Thebans', Bulletin of the Hegel Society of Great Britain, 62, 35-60.

Sandis, C. (2012), 'The Public Expression of Penitence', Teorema, 31 (2), 141-52.

Sandis, C. (2015), 'Motivated by the Gods: Compartmentalized Agency \& Responsibility', in A. Buckareff, C. Moya, \& S. Rosell (eds.), Agency and Responsibility. London: Palgrave Macmillan, 209-25.

Sandis, C. (forthcoming), 'What Is It to Do Nothing?', in V. Rodríguez-Blanco \& G. Pavlakos (eds.), Negligence, Omissions and Responsibility: Reflecting on Philosophy of Action. Cambridge: Cambridge University Press.

Scanlon, T. M. (2008), Moral Dimensions: Permissibility, Meaning, Blame. Cambridge MA: Harvard University Press.

Scher, G. (2009), Who Knew? Responsibility Without Awareness. Oxford: Oxford University Press.

Sorell, T. \& Rogers, G.A.J. (eds.) (2005), Analytic Philosophy and History of Philosophy. Oxford: Oxford University Press.

Stepelevich, L. \& Lamb, D. (eds.) (1983), Hegel's Philosophy of Action. Atlantic Highlands NJ: Humanities Press.

Taylor, C. (1983), 'Hegel and the Philosophy of Action' in Stepelevitch \& Lamb 1983: 1-18. Vice, S. (2011), 'Why My Opinions on Whiteness Touched a Nerve', Mail \& Guardian, 2 Sep. Williams, G. (1961), Criminal Law: The General Part. London: Steven \& Sons.

Williams, B. (1976), 'Moral Luck', Proceedings of the Aristotelian Society, Supplementary Volume 50, 115-35.

Williams, B. (1993), Shame and Necessity. Cambridge: Cambridge University Press.

Wood, A. W. (2010), 'Hegel on Responsibility for Actions and Consequences', in Laitinen \& Sandis 2010, 119-36. 
Yeomans, C. (2012), Freedom and Reflection: Hegel and the Logic of Agency. Oxford: Oxford University Press.

Yeomans, C. (2015), The Expansion of Autonomy: Hegel's Pluralistic Philosophy of Action. Oxford: Oxford University Press.

Yeomans, C. (2017), 'Hegel's Philosophy of Action', in D. Moyar (ed.), The Oxford Handbook of Hegel. Oxford: Oxford University Press, 475-95.

Zimmerman, M. J. (2009), 'Responsibility and Awareness', Philosophical Books, 50 (4), 24826.

\footnotetext{
${ }^{1}$ There has been a flood of books and articles on Hegel's philosophy of action during recent decades, see for example, Stepelevich \& Lamb 1983, Quante 2004, and Laitinen \& Sandis 2010.

${ }^{2}$ We see the merit of both 'analytic' and 'contextualist' (or 'antiquarian') history of philosophy (see Sorell \& Rogers 2005), but agree with Anthony Kenny that one may legitimately write about the arguments of past philosophers without engaging in any kind of historiography (Kenny 2005: 13; see also Sandis 2009).

${ }^{3}$ See Laitinen, Mayr, \& Sandis 2018: 107-8.

${ }^{4}$ No special sympathy towards agent causation (as opposed to event causation) is intended here. See Knowles 2010 and Pippin 2010.

${ }^{5}$ See Laitinen, Mayr, \& Sandis 2018; cf. Wood 2010.

${ }^{6}$ On actions as externalizations of purposes, see Taylor 1983, Pippin 2010, and Knowles 2010.

${ }^{7}$ Note that 'responsibility' here refers to moral responsibility, whereas in $P R$ : $\S 115 Z$ (as quoted at the start of Part I) 'responsible' is used to denote causal responsibility.

${ }^{8}$ Cf. Sandis 2010 and Falkenstern 2018.

${ }^{9}$ Katerina Deligiorgi suggested to us that Hegel thinks that there are as such actions that are not deeds e.g. mental acts such as reciting the words of a poem in one's head.

${ }^{10}$ Cf. $P R: \$ 118 Z, P R \S 119$.

${ }^{11}$ See note 7 above.
}

12 Thanks to Edgar Maraguat for raising the worry that our actions can be ours in a sense in which our dog cannot. Is it reasonable to extend accountability from one sense of ownership to another? The matter is a complicated one. The child of a Nazi criminal may rightly be troubled by the fact that certain atrocities were performed by her parents, even though she does not own her parents, not even in the sense in which she might be said to own her own child or, indeed, her parents when elderly and under her care. While we are not strictly liable for the past actions of our parents or ancestors, it remains plausible there are circumstances in which our knowledge of them should make us feel shame and seek to pay reparations (see Vice 2011). Such reactions run parallel to those associated with 'agent regret' over our own behavior (cf. Bowra 1944: 168-70, Dodds 1951: 30ff., Williams 1993: 69-70, Denham 2014, \& Sandis 2015: 220ff.).

${ }^{13}$ See Sandis, forthcoming.

${ }^{14}$ Quante 2004 writes that 'purpose' and 'intention' are different in the categories of Hegel's logic that they use. He does not consider the possibility, however, that purpose includes what one should have foreseen. But unless it includes this, one cannot be accountable for what one should have foreseen, on pain of being accountable for more than what is in one's purpose.

${ }^{15}$ He further notes that the word 'motive' can refer both to the intention as a whole, or a (particular) aspect of that intention: 'The motive [Beweggrund] of a deed ... has two meanings — the universal [i.e. intention] which is inherent in the purpose, and the particular aspect of the intention' (PR: $§ 121 \mathrm{Z})$

${ }^{16}$ See Laitinen, forthcoming.

${ }^{17}$ Cf. Sher 2009 and Zimmerman 2009. We side with Sher, who is (unknowingly) on Hegel's side. As in law, ignorance is no excuse.

${ }^{18}$ The notion of 'rational nature' of one's action plays a role here, see Wood 2010.

19 Depending on one's views on so-called negative actions, it could be argued that Hegel's notion of a 'deed' should be slightly reformulated so as to give preventions and alterations the very same standing.

${ }^{20}$ Even though actions extend further than that, since foreseen and unforeseen consequences result from the will's purpose and belong to action (see Knox 1942).

${ }^{21}$ Wood 2010.

22 Alznauer 2008, 2015.

${ }^{23}$ Hegel points out further that 'the distinction between contingent and necessary consequences is indeterminate' (PR: $\$ 118 \mathrm{R})$. 
${ }^{24}$ A similar suggestion is also made by Cargnello 2014.

${ }^{25}$ Cf. Falkenstern 2018.

${ }^{26}$ Hart 1968.

${ }^{27}$ For the view that intentionally $\phi$-ing need not involve an intention to $\phi$, cf. Williams 1961, Hart 1968, or Knobe 2003.

${ }^{28}$ This solution is thus out of line with the way in which Hegel toys with the etymology of Absicht: intention is an abstraction that does not cover the entirety of the deed, but merely contains some parts or aspects (including only those characterizations that offer the agent the point of doing the deed).

${ }^{29}$ See Sandis 2012.

${ }^{30}$ We thank Susanna Lindberg for putting the worry to us thus. Onni Hirvonen suggested to us that it is also possible that Hegel contradicts himself unintentionally and that, if so, the hard problem cannot be solved. We currently see no need to accept this, but could change our mind if our proposed solution proved unviable for some reason we have failed to consider.

${ }^{31}$ Our approach here shares many affinities with that of Christopher Yeomans' pluralist reading of 'Morality', which dismisses the importance of contradictions and the dialectical element both within 'Morality' and in the transition to 'Ethical Life' (see Yeomans 2016 \& 2017).

${ }^{32}$ Particular thanks are due to Edgar Maraguat for his extensive comments on an earlier draft. We'd also like to thank Giulia Battistini, Randolph Clarke, Karen de Boer, Katerina Deligiorgi, Onni Hirvonen, Stephen Houlgate, Susanna Lindberg, Thomas Meyer, Ken Westphal, Chris Yeomans, and Mikko Yrjönsuuri for helpful discussions and suggestions. Research for this paper was funded by the Santander Research Project Award Hegel \& Contemporary Philosophy of Action and the Research Council of the Spanish Government Project Hegel's Philosophy of Action: Logical and Ontological Aspects (FFI2013-44481-P). Earlier versions were presented at Objective Spirit - Beyond Recognition? Nordic Network for German Idealism, Helsinki (30 Oct-1 Nov, 2009), Hegel \& Collingwood, Oxford Brookes University (7 May, 2010), Hegel and the Philosophy of Action, University of Valencia (9-11 Nov, 2016), and Philosophy of Action - Contemporary and Historical Perspectives, University of Jyväskylä (22 Mar, 2019). We'd like to thank all of the organisers and participants for helpful discussions and remind the reader of Hegel's adage that 'the length of the journey has to be borne with, for every moment is necessary'. 